\title{
Tourism Multiplier in the World Economy: Covid-19 Effects*
}

\author{
Alberto Corti ${ }^{* *}$
}

\begin{abstract}
The COVID-19 pandemic has impacted on the world order with the force of a tsunami. It is important also to consider the economic aspect. In this context, tourism plays a leading role, being one of the most affected sectors - both in quantitative terms and in terms of the persistence of the negative trend-as well as, finally, for its effects on other sectors.

The result of the calculation of the correlation coefficient between the tourism percentage incidence on GDP in 2018 and 2020/2019 GDP percentage loss highlights that the higher the incidence of tourism on a country's GDP was at the beginning of the pandemic, the greater the percentage loss of GDP was for that country.
\end{abstract}

Keywords: Covid-19; Tourism; World Economy; Tourism Multiplier; Global Markets

\section{Covid-19 and World Economy}

The COVID-19 pandemic has impacted on the world order with the force of a tsunami. Started in the early 2020 in the Far East, COVID-19 was initially considered as a problem limited to the territory of the People's Republic of China and its Special Administrative Regions (SAR). The epidemic has almost really revealed its global scope spreading to the entire Far Eastern quadrant and, immediately after that, developing in Europe and the North American continent to then spread throughout the world.

The succession of phases - the so-called "epidemic waves" - and the identification of new variants, have also put a strain on the study and development of vaccines against the virus. In addition to the fact that the impact of the pandemic event on very different national health systems and that often already had structural weaknesses, has led to the continuation of the health alert practically in all corners of the world until today.

The progress of vaccination plans, in particular in the more economically advanced areas of the world such as North America, Europe and some countries in Asia and

\footnotetext{
* Invited Article

** Head of Confcommercio Tourism Sector (a.corti@ confcommercio.it)
}

Edited by: Niccolò Cusano University

ISSN: 1593-0319

Corti, A. (2021). Tourism Multiplier in the World Economy: Covid-19 Effects. Symphonya. Emerging Issues in Management (symphonya.unicusano.it), (2), 20-25.

https://dx.doi.org/10.4468/2021.2.03corti 
Oceania, would suggest that the pandemic alarm, though not over, has at least now entered a stage in which it can be kept under control.

In addition to the health catastrophe, the effects of this situation should be interpreted from the viewpoint of the impact of the crisis on the system of rules, where the pandemic has laid bare many elements of strictness, some of which have been swept aside, albeit in the logic of an exceptional and temporary approach. For instance, in order to avoid the knock-on effect for bankruptcies in the world of passenger transport and tourism operators, in many European countries it would have been allowed to refund services booked and not used by issuing vouchers to customers - instead of returning money - without the need to obtain their consent to this refund method.

It would have been hard to imagine that the binding limits to state aid in favour of companies - decided for some time at Community level - would have been completely changed, allowing aids that, in the temporary framework adopted by the European Commission, can currently reach $€ 10$ million in some cases.

\section{Covid-19: Effects on the World Tourism}

It is important also to consider the economic aspect, namely to what extent and in which way the pandemic has affected the wealth produced worldwide, the competitive scenarios and the very stability of many countries. In this context, tourism plays a leading role, being one of the most affected sectors - both in quantitative terms and in terms of the persistence of the negative trend - as well as, finally, for its effects on other sectors.

Unfortunately, the official data available on the trend in tourist flows, at world level, are incomplete and provisional.

UNWTO's World Tourism Barometer indicates 394 million international tourist arrivals in 2020, a $73.1 \%$ reduction from the 1,466 million in 2019. However, it must be pointed out that these figures do not include updated data, among others, from France, China, the United Kingdom, Portugal, Russia and India, which together accounted for $17.8 \%$ of total international arrivals in 2019 and are therefore far from being secondary. Moreover, according to UNWTO (2021), the number of international arrivals in Italy - the world's fifth most visited country in the world - is provisionally indicated in 25.4 million, whereas having already completed figures for 2020, ISTAT ${ }^{1}$ identifies only 16.4 million international arrivals in Italy. However, even taking into account the different bases of calculation used by the two sources, there are no grounds to rely on absolute values, at least for now, although the trend is certainly clear: no continent has lost less than 68\% of its foreign tourist arrivals, with peaks of up to $84 \%$. In practice, with these values, international tourism has returned to the early 1990s, stepping back in time of more than 30 years. 
The most up-to-date figures that are useful to understand the scope of the events even if only for Italy - are published by ISTAT. In our country, the pandemic crisis started in March, hence there is no need to include January and February 2020 in the calculation. Between March and December of last year, foreign tourist arrivals in Italian tourist accommodation facilities were 11,650,000 compared to 60 million in the same period of the previous year, with a drop of $80.5 \%$, to which the loss of over 29 million Italian tourists must be added ${ }^{2}$. Italy, in turn, contributed to the reduction in arrivals in other countries, for 48,850,000 travellers abroad: $-64 \%$, in the same reference period ${ }^{3}$. Getting back to Italy as a destination of international tourist flows, with regard only to "incoming", the figure emerges in all its severity if examined in terms of presences, that is, overnight stays at the destination: between March and December 2020, they were 49,957,000 against 203,843,000 in the same period of $2019^{4}$. A collapse of almost 155 million, on the component, which is mostly characterized by an average per capita expenditure that is higher than that of the domestic demand.

$\square$ The latter figure is fully reflected in the indications provided in the Economic and Financial Document (Documento di Economia e Finanza, DEF) approved by the Council of Ministers of the Italian Republic on 15 April last year. This document analyses the 2020 trend of the current account of the balance of payments states "Together with the decline in import volumes and the drop in energy prices, the recovery of exports has pushed Italy's trade surplus to 66.6 billion and the current account surplus of the balance of payments to 59.9 billion, equal to 3.6 percent of GDP. Within the current account, 'travel' was the main item bucking the trend, due to the collapse in the presence of foreign tourists in Italy which was only partially offset by lower spending abroad by Italians". This statement not only confirms the seriousness of the crisis suffered by the tourism sector in our country, but it is also evidence of its continuation well beyond the time experienced by other sectors of the economy, starting with manufacturing.

\section{Covid-19: Tourism Multiplier in the World Economy}

This brings us to the last element of the analysis presented, probably the least known: the fact that the crisis resulting from the current pandemic has been, and still is, a catastrophe that has mainly hit the world of services and, within it, that of tourism with particular violence.

A comparison of two series of data is presented in Table 1. The first series of data describes the percentage incidence of tourism on GDP of some of the main European countries in 2018, according to WTTC6. On the other hand, the second series of data describes, for the same countries, the percentage reduction in GDP recorded in 2020 compared to 2019, according to Eurostat ${ }^{7}$. The difference in the reference years of the two statistical series should not be misleading.

In particular, the first series describing the percentage incidence of tourism on GDP of each country includes data that change very slowly over time: for instance, for 
Italy and always according to the same source, the result of this calculation has always been between $13 \%$ and $14 \%$ over the last 10 years. It is therefore highly likely, not to say certain, that the percentage incidences of tourism on GDP in the 12 European countries considered below were identical in 2018 and 2019 and that, therefore, it was the starting point for the same countries at the beginning of 2020.

Table 1: Tourism \% Incidence on GDP in 2018 and 2020/2019 GDP \% Loss

\begin{tabular}{|l|c|c|c|c|c|c|c|c|c|c|c|c|}
\hline & GR & PT & AT & ES & IT & FR & DE & SE & FI & BE & NL & DK \\
\hline $\begin{array}{l}\text { TOURISM } \\
\text { PERCENTAGE } \\
\begin{array}{l}\text { INCIDENCE ON } \\
\text { GDP IN 2018 }\end{array}\end{array}$ & 21 & 19 & 15 & 15 & 13 & 10 & 9 & 9 & 9 & 8 & 5 & 5 \\
\hline $\begin{array}{l}\text { 2020/2019 GDP } \\
\text { PERCENTAGE } \\
\text { LOSS }\end{array}$ & 8.2 & 7.6 & 6.6 & 10.8 & 8.9 & 8.1 & 4.8 & 2.8 & 2.8 & 6.3 & 3.7 & 2.7 \\
\hline
\end{tabular}

The result of the calculation of the correlation coefficient between the functions outlined by the two series of data is 0.7 , indicating not only a positive correlation where, therefore, the values tend to change in parallel - but also that the two variables are closely connected. In summary, the higher the incidence of tourism on a country's GDP was at the beginning of the pandemic, the greater the percentage loss of GDP was for that country.

Moreover, the calculation of the coefficient connecting the two variables, equal to 0.506017, in the series under review indicates that for each point in the percentage incidence of tourism on GDP of the countries taken into consideration at the beginning of the pandemic, the overall loss of gross product recorded in the same countries during the pandemic would have increased by 0.5 percentage point. Thus, the degree of dependence of individual national economies on tourism would explain as much as half of the decrease in GDP recorded in 2020. If confirmed with more indepth analyses based on larger statistical series, this order of magnitude would indicate an effect of tourism spending on direct, indirect and allied benefit even more marked compared to data presented until now with the most advanced econometric models applied.

First and foremost, the calculation of the tourism satellite account in each country, which is the internationally recommended and recognized tool for the economic measurement of tourism, and it is developed by the respective central statistical offices - ISTAT in Italy - with methodologies that detect tourism consumption and production in order to determine the effective weight of the sector on the national economy.

Therefore, it is safe to state that the crisis of the COVID-19 pandemic was, above all, a crisis of tourism, even if there are many other elements that may have influenced the relation just analysed: one for all, the fact that the various countries had different approaches to the measures to contain the spread of the virus. Some in fact - all nonEuropean - have opted for the LFT protocol (Lockdown, Case Finding, Mobile Tracking), which is the approach adopted with a good level of success in China. In 2019, China recorded 65.7 million international tourist arrivals, of which it would be interesting to analyse in more detail the composition by origin since, in the same year and according to the same source, the value of revenues from these flows amounted 
to $\$ 35.8$ billion, thus equal to $\$ 545$ per international tourist compared to $\$ 770$ recorded in Italy.

Whereas other countries have adopted the LSG (Lockdown Stop and Go) protocol and others opted for a combination of the two foregoing protocols, as in the case of Finland and Denmark among the countries included in the calculation. It emerges clearly that each of these solutions had different impacts on the economic system of the different areas taken into consideration.

However, it must be said that the results obtained are not surprising at all. Getting back to the relation identified, the fact does not determine with certainty the existence of a cause-effect relationship between the two quantities, especially given the limited number of data taken into consideration.

First of all, because being a service, tourism cannot produce for stocks, as it is the case, for instance, in manufacturing, so the effect of changes in demand affects sales in a much more immediate way, and therefore the value of production and, finally, GDP: this is a feature that tourism has in common with all other services.

Whereas it is much more specific, the second feature which, in our opinion, underlies the relation identified above. To introduce it, we need to start from the definition of "tourist" itself, adopted practically worldwide: any person who, for reasons not only of vacation but also of work, health, study, etc., moves from the place where he or she normally resides and reaches a different town or country, where he or she must stay overnight because, otherwise, instead of being a tourist is an excursionist. If we think about what happened in Italy, in Europe and in the world in the various more or less intense and prolonged lockdown periods, the flows of goods have been blocked very rarely, whereas the flows of people have always been at the centre of the restrictive measures of movements that were introduced. Therefore, one of the few scenarios, which is, actually opposite to the possibility of developing both international and domestic tourist flows, has occurred.

Tourism has been negatively affected by the obligation to close the activities that make up its supply chain, which in many cases have been authorized to remain open or obliged to reduce the use of space and opening hours without closing. Moreover, tourism has suffered much more heavily from the "closing" of the users of its services, who have been temporarily prevented from performing the act that turns them from potential users into tourists, i.e., moving outside their usual place of residence.

\section{Bibliography}

Assaf, A. G., \& Josiassen, A. (2012). Identifying and Ranking the Determinants of Tourism Performance: A Global Investigation. Journal of Travel Research, 51(4), 388-399.

http://dx.doi.org/10.1177/0047287511426337

Bellini, N., \& Convert, L. (2016). The Concierge. Tradition, Obsolescence and Innovation in Tourism, Symphonya. Emerging Issues in Management (symphonya.unimib.it), (2), 17-25.

http://dx.doi.org/10.4468/2016.2.03bellini.convert

Bellini, N. (2015). Smart Specialisation in Europe: Looking Beyond Regional Borders. Symphonya. Emerging Issues in Management (symphonya.unimib.it), (1), 22-29.

http://dx.doi.org/10.4468/2015.1.03bellini 
Bellow, E., Majd, T., \& Casalegno, C. (2019). Creative and Sustainable Tourism: The Case of Ainu in Japan. Symphonya. Emerging Issues in Management (symphonya.unicusano.it), (2), 119-132. http://dx.doi.org/10.4468/2019.2.11bellow.majd.casalegno

Brida, J. G., Cortes-Jimenez, I., \& Pulina, M. (2016). Has the Tourism-Led Growth Hypothesis Been Validated? A Literature Review. Current Issues in Tourism, 19(5), 394-430.

http://dx.doi.org/10.1080/13683500.2013.868414

Brondoni, S. M., \& Rizzi, P. (2017). Ouverture de 'Special Issue on Global Tourism. Symphonya. Emerging Issues in Management (symphonya.unimib.it), (3), 1-10.

http://dx.doi.org/10.4468/2017.3.01ouverture

Brondoni, S. M. (2016). Global Tourism Management. Mass, Experience and Sensations Tourism, Symphonya. Emerging Issues in Management (symphonya.unimib.it), (1), 7-24.

http://dx.doi.org/10.4468/2016.1.02brondoni

Brondoni, S. M. (2016). Global Tourism and Terrorism. Safety and Security Management, Symphonya. Emerging Issues in Management (symphonya.unimib.it), (2), 7-16.

http://dx.doi.org/10.4468/2016.2.02brondoni

Corti, A. (2016). Global Tourism New Volatility, Old Statistics. Symphonya. Emerging Issues in Management (symphonya.unimib.it), (1), 25-30.

http://dx.doi.org/10.4468/2016.1.03corti

Gössling, S., \& Peeters, P. (2015). Assessing Tourism's Global Environmental Impact 1900-2050. Journal of Sustainable Tourism, 23(5), 639-659.

http://dx.doi.org/10.1080/09669582.2015.1008500

Li, K. X., Jin, M., \& Shi, W. (2018). Tourism as an Important Impetus to Promoting Economic Growth: A Critical Review. Tourism Management Perspectives, 26, 135-142.

http://dx.doi.org/10.1016/J.TMP.2017.10.002

Papatheodorou, A., \& Song, H. (2005). International Tourism Forecasts: Time-Series Analysis of World and Regional Data. Tourism Economics, 11(1), 11-23.

http://dx.doi.org/10.5367/0000000053297167

Rizzi, P., \& Graziano, P. (2017). Regional Perspective on Global Trends in Tourism, Symphonya. Emerging Issues in Management (symphonya.unimib.it), (3), 11-26.

http://dx.doi.org/10.4468/2017.3.02rizzi.graziano

Salvioni, D. M. (2016). Hotel Chains and the Sharing Economy in Global Tourism, Symphonya. Emerging Issues in Management (symphonya.unimib.it), (1), 31-44.

http://dx.doi.org/10.4468/2016.1.04salvioni

UNWTO (2016). Tourism Highlights. 2016 Edition. Madrid.

UNWTO (2016). World Tourism Barometer. 14 May.

UNWTO (2021). World Tourism Barometer, (19)2, March.

\footnotetext{
Notes

${ }^{1}$ ISTAT Istituto Nazionale di Statistica - ISTAT Database.

${ }^{2}$ Confturismo-Confcommercio processing ISTAT data.

${ }^{3}$ Confturismo-Confcommercio processing on Bank of Italy data:

https://www.bancaditalia.it/statistiche/tematiche/rapporti-estero/turismo-internazionale/index.html

${ }^{4}$ Confturismo-Confcommercio processing ISTAT data.

${ }^{5}$ DEF - Economic and Financial Document, 2021 approved by the Italian Cabinet on 15 April 2021.

${ }^{6}$ WTTC: World Travel \& Tourism Council.

${ }^{7}$ EUROSTAT, Statistical Office of the European Union.
} 